\title{
Anti-Melanogenic Properties of Velutin and Its Analogs ${ }^{\dagger}$
}

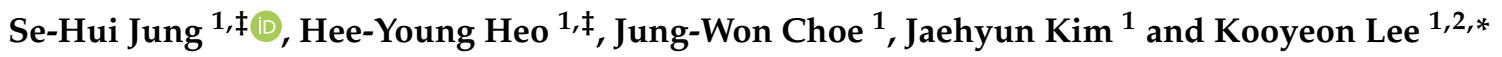 \\ 1 Department of Bio-Health Technology, Division of Biomedical Convergence, College of Biomedical Science, \\ Kangwon National University, Chuncheon 24341, Korea; 96-shjung@hanmail.net (S.-H.J.); \\ gmldud940315@naver.com (H.-Y.H.); cjh9531@naver.com (J.-W.C.); 1342113@naver.com (J.K.) \\ 2 Research Institute, K-medichem Co., Ltd., Chuncheon 24341, Korea \\ * Correspondence: 1ky@kangwon.ac.kr; Tel.: +82-33-250-6477 \\ + Dedicated to Prof. Phil-Ho Lee on his 60th Birthday. \\ $\ddagger$ These authors contributed equally to this work.
}

check for updates

Citation: Jung, S.-H.; Heo, H.-Y.;

Choe, J.-W.; Kim, J.; Lee, K.

Anti-Melanogenic Properties of Velutin and Its Analogs. Molecules 2021, 26, 3033. https://doi.org/ $10.3390 /$ molecules 26103033

Academic Editor: H. P. Vasantha Rupasinghe

Received: 19 April 2021

Accepted: 14 May 2021

Published: 19 May 2021

Publisher's Note: MDPI stays neutral with regard to jurisdictional claims in published maps and institutional affiliations.

Copyright: (C) 2021 by the authors. Licensee MDPI, Basel, Switzerland. This article is an open access article distributed under the terms and conditions of the Creative Commons Attribution (CC BY) license (https:// creativecommons.org/licenses/by/ $4.0 /)$.

\begin{abstract}
Velutin, one of the flavones contained in natural plants, has various beneficial activities, such as skin whitening, as well as anti-inflammatory, anti-allergic, antioxidant, and antimicrobial activities. However, the relationship between the structure of velutin and its anti-melanogenesis activity is not yet investigated. In this study, we obtained 12 velutin derivatives substituted at C5, C7, $\mathrm{C}^{\prime}$, and $\mathrm{C}^{\prime}$ of the flavone backbone with hydrogen, hydroxyl, and methoxy functionalities by chemical synthesis, to perform SAR analysis of velutin structural analogues. The SAR study revealed that the substitution of functional groups at $\mathrm{C} 5, \mathrm{C} 7, \mathrm{C}^{\prime}$, and $\mathrm{C}^{\prime}$ of the flavone backbone affects biological activities related to melanin synthesis. The coexistence of hydroxyl and methoxy at the C5 and C7 position is essential for inhibiting tyrosinase activity. However, 1,2-diol compounds substituted at $\mathrm{C}^{\prime}$ and $\mathrm{C}^{\prime}$ of flavone backbone induce apoptosis of melanoma cells. Further, substitution at $\mathrm{C}^{\prime}$ and $\mathrm{C}^{\prime}{ }^{\prime}$ with methoxy or hydrogen is essential for inhibiting melanogenesis. Thus, this study would be helpful for the development of natural-derived functional materials to regulate melanin synthesis.
\end{abstract}

Keywords: velutin derivatives; melanin synthesis; tyrosinase activity; SAR study

\section{Introduction}

Flavones, a type of flavonoid consisting of two phenyl rings and a benzopyran functionality, are widely present in natural plants, including vegetables and fruits [1]. In many compounds, the flavone scaffolds are considered important core structures that act on various targets molecules via simple modifications. In particular, flavone derivatives with metabolic or synthetic modification are known to have anti-inflammatory, antiestrogenic, anti-allergic, antioxidant, antimicrobial, antitumor, and anti-proliferation activities [2-4]. Furthermore, simple substitution of the flavone backbone with functional groups like hydroxyl and methoxy, results in very different biological activities. Due to the broad biological activities of flavones, their structure-activity relationship (SAR) attracted interest in the field of medicinal chemistry, which helped to discover some lead compounds to alleviate numerous diseases. For example, the previous SAR study revealed that, as the number of hydroxyl groups increased, the radical scavenging effect of flavones increased [5].

Melanin is a natural pigment that is involved in the determination of skin, eye, and hair color, and has an important role in the protection of skin from damage by harmful light, such as ultraviolet rays [6-8]. Despite its beneficial effects, abnormal regulation of melanin synthesis is responsible for pigmentary disorders that include albinism, vitiligo, melasma, freckles, and lentigo $[9,10]$. Melanin is synthesized in melanocytes, which are specialized cells located at the basal layer of the epidermis, through multistep catalytic reactions of enzymes such as tyrosinase, tyrosinase-related protein 1, and tyrosinase-related protein $2[9,11]$. Tyrosinase plays a key role in the two rate-limiting reactions of melanin synthesis, by the hydroxylation of L-tyrosine to L-3,4-dihydroxyphenylalanine (L-DOPA), and the oxidation of L-DOPA to dopaquinone [12]. Thus, various regulators of the tyrosinase 
activity were studied for treating pigmentary disorders [13]. Whitening reagents based on tyrosinase inhibition, such as hydroquinone, azelaic acid, arbutin, and kojic acid, were reported to prevent skin hyperpigmentation $[11,14]$. However, due to their cellular toxicity, low efficacy, and low stability in the presence of oxygen and water, whitening ingredients from natural products are considered in the cosmetic research and development field to be an alternative strategy to prevent hyperpigmentation.

Velutin belongs to a class of flavonoids that have hydroxyl, methoxy, methoxy, and hydroxyl groups at $\mathrm{C} 5, \mathrm{C} 7, \mathrm{C}^{\prime}$, and $\mathrm{C}^{\prime}$ of the flavone backbone, respectively (Figure 1). Velutin is found in the pulp of acai fruit, and is known to exhibit anti-inflammatory and antioxidant activities $[15,16]$. Furthermore, velutin obtained by the deglycosylation of homoflavoyadorinin B in mistletoe extract has an inhibitory effect on tyrosinase and melanogenesis [8]. However, the relationship between the structural modification of velutin and its anti-tyrosinase and anti-melanogenesis activities are not yet investigated.<smiles>[R]c1cc([R2])c2c(=O)cc(-c3ccc([R4])c([R9])c3)oc2c1</smiles>

Figure 1. The chemical structure of flavones.

In this study, we prepared 12 velutin derivatives by substitution at $C 5, C 7, C 3^{\prime}$, and $\mathrm{C}^{\prime}$ ' of the flavone backbone with hydrogen, hydroxyl, and methoxy functionalities, to perform SAR analysis of the velutin structural analogues. All 12 derivatives were evaluated for their inhibitory activity against tyrosinase activity and melanogenesis. We found that the coexistence of the methoxy group at the C7 position and hydroxyl groups at the C5 and $\mathrm{C}^{\prime}$ ' positions in the flavone skeleton was essential to have inhibitory activity. In addition, the 1,2-diol form with hydroxyl groups at the $\mathrm{C}^{\prime}$ and $\mathrm{C}^{\prime}$ positions of the flavone induced apoptosis in the melanoma cells. Thus, these findings would be helpful for investigating the effect of flavone derivatives on the biosynthesis of melanin, and for developing new chemical drugs to suppress melanin synthesis.

\section{Results and Discussion}

\subsection{Chemical Synthesis of Velutin Derivatives}

In order to understand the relationship between the structural modification of the velutin backbone and its biological activities, eleven velutin derivatives (V1-V12, except V11) were chemically synthesized from 2-hydroxy acetophenone derivatives and aromatic aldehyde derivatives, via five-step conventional methods [17]. Three velutin derivatives, V1 (velutin), V5, and V8, were synthesized via a seven-step reaction, as shown in Scheme 1. First, to synthesize 1-(2-(benzyloxy)-6-hydroxy-4-methoxyphenyl)ethan-1one (V1e), bis-MOM-protected acetophenone (V1b) was synthesized from commercially available $2^{\prime}, 4^{\prime}, 6^{\prime}$-trihydroxyacetophenone (V1a), subjected to deprotection reaction, after synthesis of benzylated acetophenone (V1c), and selective substitution of the methoxy group at the C4 position of 1-(2-(benzyloxy)-4,6-dihydroxyphenyl)ethan-1-one (V1d) was performed. Then, V1, V5, and V8 derivatives were synthesized by the subsequent aldol condensation, oxidative cyclization, and reduction from the modified acetophenone (V1e). 

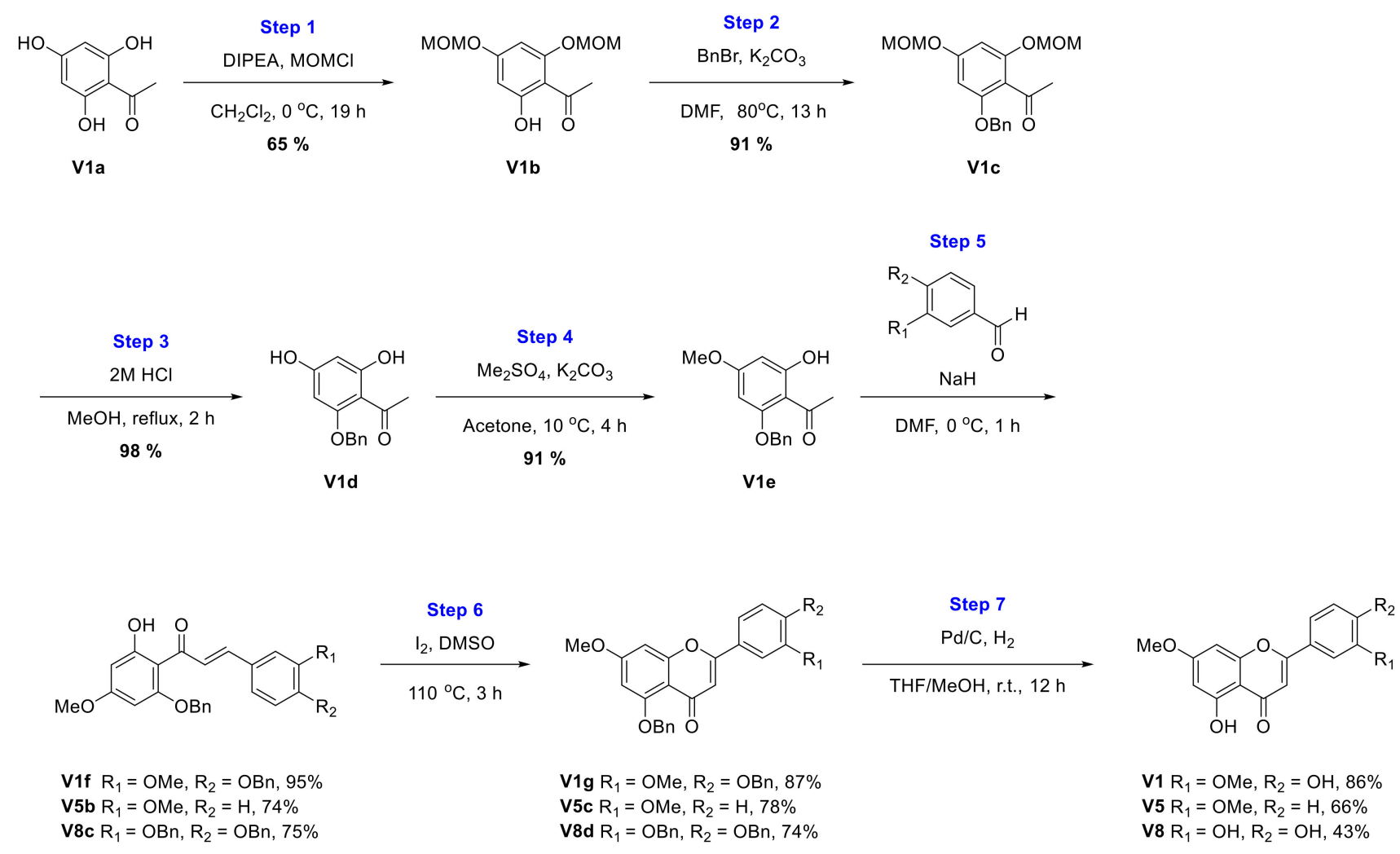

Scheme 1. Synthesis of V1, V5, and V8 derivatives.

V2 and V3 were synthesized via subsequent reactions, as shown in Scheme 2; Oalkylation at R2 and R1 of the commercially available two dihydroxyacetophnone compounds, aldol condensation, oxidative cyclization, and deprotection.

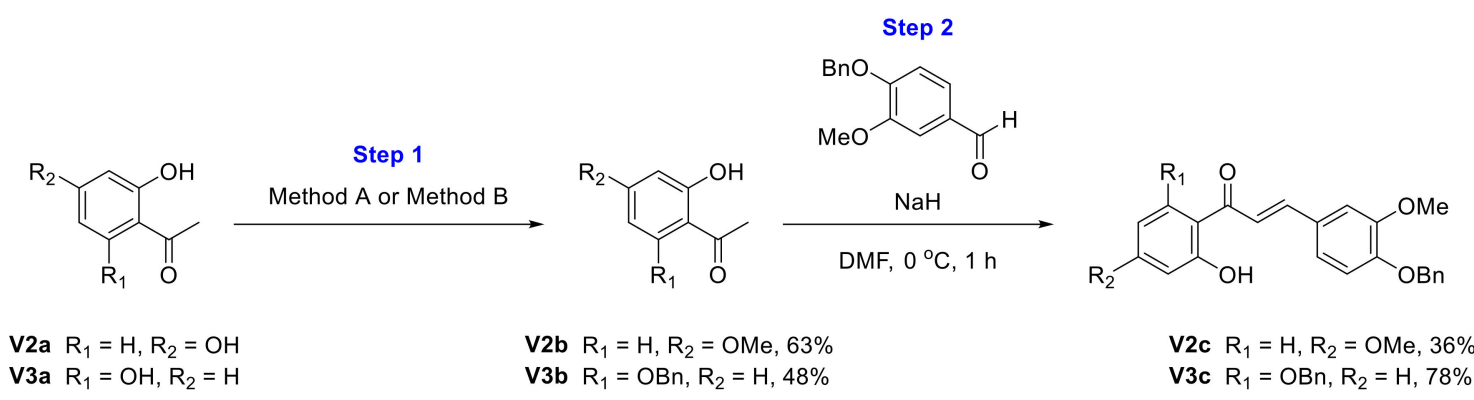

V2a: Method A) $\mathrm{Me}_{2} \mathrm{SO}_{4}, \mathrm{~K}_{2} \mathrm{CO}_{3}$ Acetone, reflux, 20 min V3a: Method B) $\mathrm{K}_{2} \mathrm{CO}_{3}, \mathrm{BnBr}, \mathrm{CH}_{3} \mathrm{CN}$, reflux, $4 \mathrm{~h}$

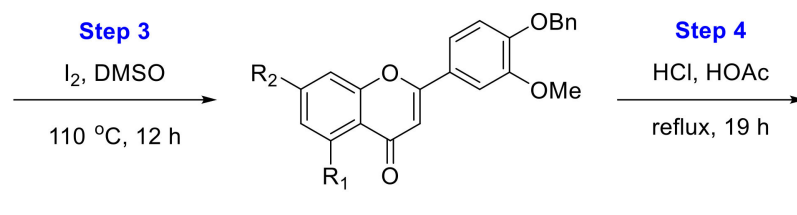

V2d $R_{1}=H, R_{2}=O M e, 80 \%$ V3d $R_{1}=O B n, R_{2}=H, 84 \%$<smiles>[R]c1cc([R])c2c(=O)cc(-c3ccc(O)c(OC)c3)oc2c1</smiles>

V2 $\mathrm{R}_{1}=\mathrm{H}, \mathrm{R}_{2}=\mathrm{OMe}, 70 \%$ V3 $\mathrm{R}_{1}=\mathrm{OH}, \mathrm{R}_{2}=\mathrm{H}, 51 \%$

Scheme 2. Synthesis of V2 and V3 derivatives.

Four derivatives, including V4, V6, V9, and V10 were synthesized via subsequent reactions, as shown in Scheme 3; O-alkylation at C4 and C6 of the commercially available 
$2^{\prime}, 4^{\prime}, 6^{\prime}$-trihydroxyacetophnone compound (V1a), aldol condensation, oxidative cyclization, and deprotection.
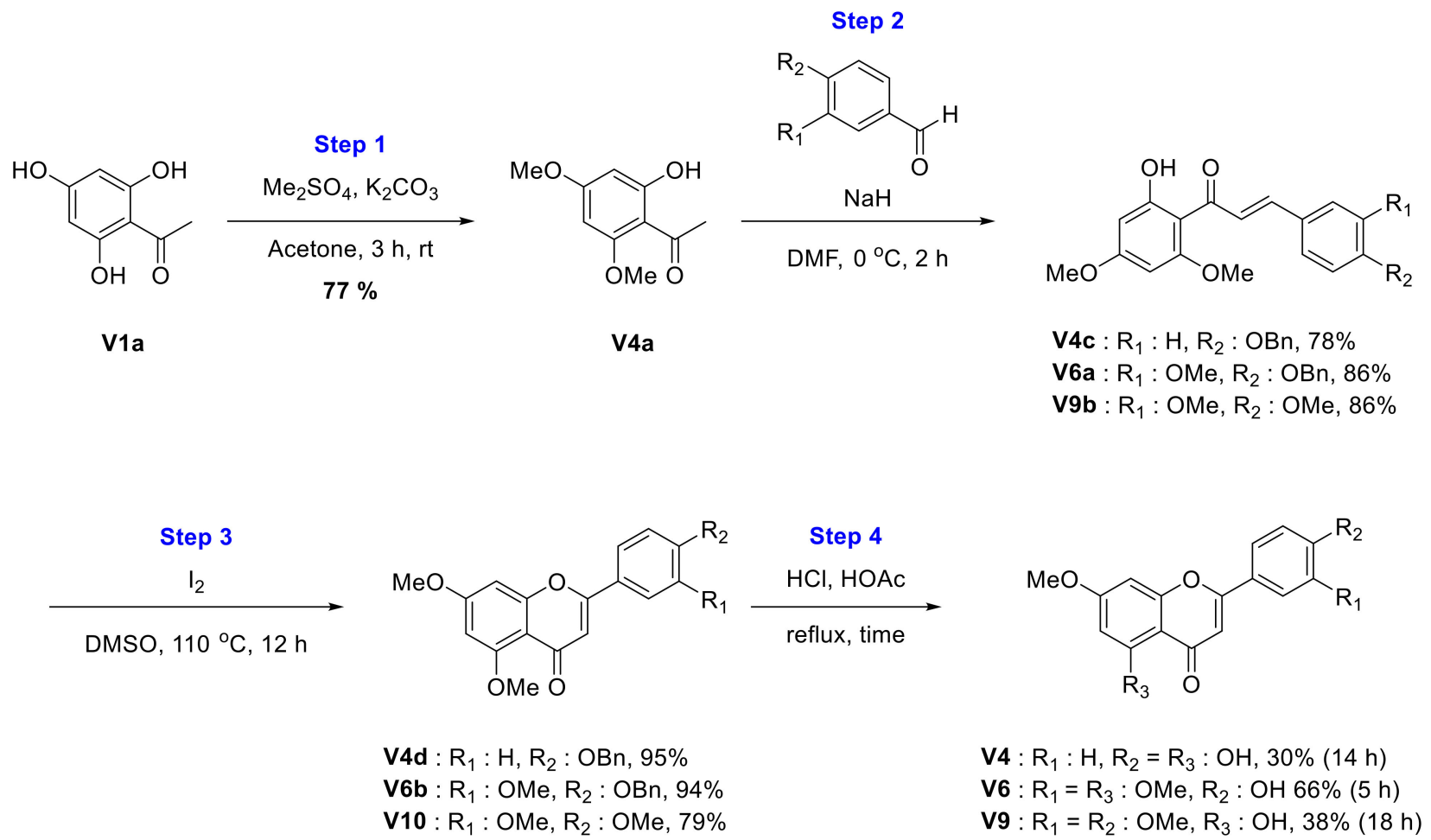

Scheme 3. Synthesis of V4, V6, V9, and V10 derivatives.

The V7 derivative was synthesized via subsequent reactions, as shown in Scheme 4; benzyl protection at $C 4$ and $C 6$ of the commercially available $2^{\prime}, 4^{\prime}, 6^{\prime}$-trihydroxyacetophnone compound (V1a), aldol condensation, oxidative cyclization, and reduction.
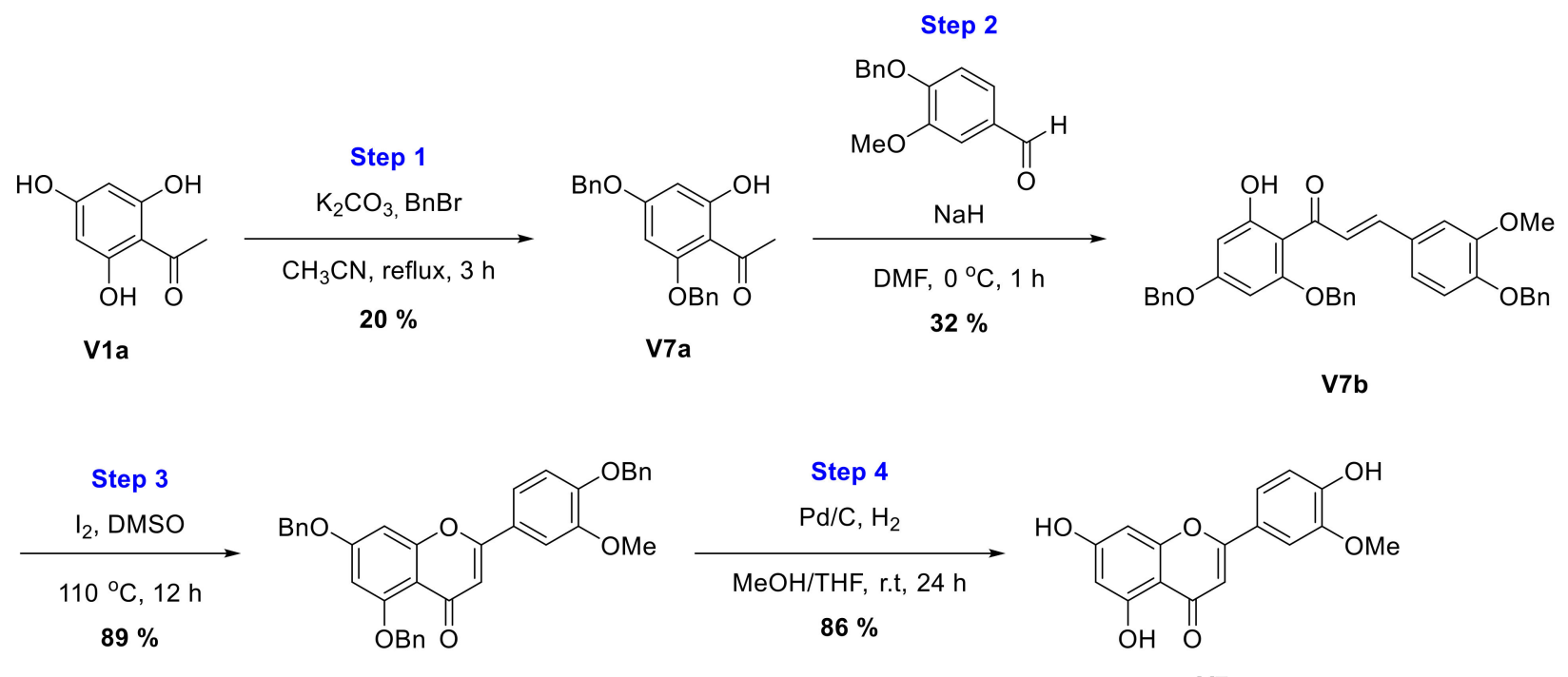<smiles>COc1cc(-c2cc(=O)c3c(O)cc(O)cc3o2)ccc1O</smiles>

Scheme 4. Synthesis of V4, V6, V7, V9, and V10 derivatives.

V12 derivative was synthesized via a two-step reaction, as previously reported [18]; aldol condensation of two commercially available 2'-hydroxyacetophnone and benzaldehyde, and oxidative cyclization. 
Table 1 summarizes the substitution group and the overall yield of the synthesized velutin derivatives.

Table 1. Substitution group and overall yield of the synthesized velutin derivatives.

\begin{tabular}{|c|c|c|c|c|c|}
\hline Compound & $\mathbf{R}^{1}$ & $\mathbf{R}^{2}$ & $\mathbf{R}^{3}$ & $\mathbf{R}^{4}$ & Total Yield (\%) \\
\hline V1 & $\mathrm{OH}$ & $\mathrm{OMe}$ & $\mathrm{OMe}$ & $\mathrm{OH}$ & 38 \\
\hline V2 & $\mathrm{H}$ & $\mathrm{OMe}$ & $\mathrm{OMe}$ & $\mathrm{OH}$ & 18 \\
\hline V3 & $\mathrm{OH}$ & $\mathrm{H}$ & $\mathrm{OMe}$ & $\mathrm{H}$ & 16 \\
\hline V4 & $\mathrm{OH}$ & $\mathrm{OMe}$ & $\mathrm{H}$ & $\mathrm{OH}$ & 17 \\
\hline V5 & $\mathrm{OH}$ & $\mathrm{OMe}$ & OMe & $\mathrm{H}$ & 20 \\
\hline V6 & $\mathrm{OMe}$ & $\mathrm{OMe}$ & OMe & $\mathrm{OH}$ & 49 \\
\hline V7 & $\mathrm{OH}$ & $\mathrm{OH}$ & $\mathrm{OMe}$ & $\mathrm{OH}$ & 22 \\
\hline V8 & $\mathrm{OH}$ & $\mathrm{OMe}$ & $\mathrm{OH}$ & $\mathrm{OH}$ & 13 \\
\hline V9 & $\mathrm{OH}$ & $\mathrm{OMe}$ & OMe & $\mathrm{OMe}$ & 20 \\
\hline V10 & $\mathrm{OMe}$ & $\mathrm{OMe}$ & $\mathrm{OMe}$ & $\mathrm{OMe}$ & 52 \\
\hline V11 & $\mathrm{OH}$ & $\mathrm{OH}$ & $\mathrm{OH}$ & $\mathrm{OH}$ & - \\
\hline V12 & $\mathrm{H}$ & $\mathrm{H}$ & $\mathrm{H}$ & $\mathrm{H}$ & 78 \\
\hline
\end{tabular}

2.2. Characterization of Synthetic Velutin Derivatives

2.2.1. Synthesis of Velutin (V1)

(V1): ${ }^{1} \mathrm{H}$ NMR (400 Mhz, DMSO-d 6 ) $\delta(12.97$ (s, 1H), 10.01 (br, s, 1H), (7.61-7.59) (m, $2 \mathrm{H}),(6.96-6.94)(\mathrm{m}, 2 \mathrm{H}), 6.80(\mathrm{~d}, J=1.52 \mathrm{~Hz}, 1 \mathrm{H}), 6.37(\mathrm{~d}, J=2.08 \mathrm{~Hz}, 1 \mathrm{H}), 3.91(\mathrm{~s}, 3 \mathrm{H}), 3.88$ $(\mathrm{s}, 3 \mathrm{H}))$.

2.2.2. Synthesis of 2-(4-Hydroxy-3-methoxyphenyl)-7-methoxy-4H-chromen-4-one (V2)

(V2): ${ }^{1} \mathrm{H}$ NMR $(400 \mathrm{Mhz}$, DMSO-d 6 ) $\delta(9.88(\mathrm{~s}, 1 \mathrm{H}), 7.92(\mathrm{~d}, J=8.84 \mathrm{~Hz}, 1 \mathrm{H}),(7.61-7.58)$ $(\mathrm{m}, 2 \mathrm{H}), 7.32(\mathrm{~d}, J=2.36 \mathrm{~Hz}, 1 \mathrm{H}), 7.05\left(\mathrm{dd}, J_{1}=8.80 \mathrm{~Hz}, J_{2}=2.40 \mathrm{~Hz}, 1 \mathrm{H}\right),(6.95-6.93)(\mathrm{m}$, $1 \mathrm{H}), 6.89(\mathrm{~s}, 1 \mathrm{H}), 3.92(\mathrm{~s}, 3 \mathrm{H}), 3.91(\mathrm{~s}, 3 \mathrm{H}))$.

2.2.3. Synthesis of 5-Hydroxy-2-(4-hydroxy-3-methoxyphenyl)-4H-chromen-4-one (V3)

(V3): ${ }^{1} \mathrm{H}$ NMR $\left(400 \mathrm{Mhz}\right.$, DMSO-d $\left.\mathrm{d}_{6}\right) \delta(12.85(\mathrm{~s}, 1 \mathrm{H}),(7.69-7.62)(\mathrm{m}, 3 \mathrm{H}), 7.21(\mathrm{~d}$, $J=8.36 \mathrm{~Hz}, 1 \mathrm{H}), 7.07(\mathrm{~s}, 1 \mathrm{H}), 6.96(\mathrm{~d}, J=8.16 \mathrm{~Hz}, 1 \mathrm{H}), 6.81(\mathrm{~d}, J=8.16 \mathrm{~Hz}, 1 \mathrm{H}), 3.91(\mathrm{~s}, 3 \mathrm{H}))$.

\subsubsection{Synthesis of Genkwanin (V4)}

(V4): ${ }^{1} \mathrm{H}$ NMR (400 Mhz, DMSO-d 6 ) $\delta(12.96(\mathrm{~s}, 1 \mathrm{H}),(7.97-7.95)(\mathrm{m}, 2 \mathrm{H}),(6.95-6.92)$ $(\mathrm{m}, 2 \mathrm{H}), 6.85(\mathrm{~s}, 1 \mathrm{H}), 6.77(\mathrm{~d}, J=2.24 \mathrm{~Hz}, 1 \mathrm{H}), 6.38(\mathrm{~d}, J=2.28 \mathrm{~Hz}, 1 \mathrm{H}), 3.87(\mathrm{~s}, 3 \mathrm{H}))$.

2.2.5. Synthesis of 5-Hydroxy-7-methoxy-2-(3-methoxyphenyl)-4H-chromen-4-one (V5)

(V5): ${ }^{1} \mathrm{H}$ NMR (400 Mhz, $\left.\mathrm{CDCl}_{3}\right) \delta(12.71(\mathrm{~s}, 1 \mathrm{H}),(7.45-7.39)(\mathrm{m}, 3 \mathrm{H}),(7.10-7.07)(\mathrm{m}$, $1 \mathrm{H}), 6.65(\mathrm{~s}, 1 \mathrm{H}), 6.50(\mathrm{~d}, J=2.28 \mathrm{~Hz}, 1 \mathrm{H}), 6.38(\mathrm{~d}, J=2.24 \mathrm{~Hz}, 1 \mathrm{H}), 3.90(\mathrm{~s}, 3 \mathrm{H}), 3.89(\mathrm{~s}, 3 \mathrm{H}))$.

2.2.6. Synthesis of 2-(4-Hydroxy-3-methoxyphenyl)-5,7-dimethoxy-4H-chromen-4-one (V6)

(V6): ${ }^{1} \mathrm{H}$ NMR (400 Mhz, DMSO-d 6 ) $\delta(7.53-7.52)(\mathrm{m}, 2 \mathrm{H}),(6.93-6.86)(\mathrm{m}, 1 \mathrm{H}), 6.86(\mathrm{~d}$, $J=2.24 \mathrm{~Hz}, 1 \mathrm{H}), 6.49(\mathrm{~d}, J=2.20 \mathrm{~Hz}, 1 \mathrm{H}), 3.90(\mathrm{~s}, 3 \mathrm{H}), 3.89(\mathrm{~s}, 3 \mathrm{H}), 3.83(\mathrm{~s}, 3 \mathrm{H}))$.

2.2.7. Synthesis of Chrysoeriol (V7)

(V7): ${ }^{1} \mathrm{H}$ NMR (400 Mhz, DMSO-d 6 ) $\delta(12.97(\mathrm{~s}, 1 \mathrm{H}),(7.57-7.55)(\mathrm{m}, 1 \mathrm{H}), 6.93(\mathrm{~d}$, $J=8.92 \mathrm{~Hz}, 1 \mathrm{H}), 6.88(\mathrm{~s}, 1 \mathrm{H}), 6.47(\mathrm{~d}, J=1.87 \mathrm{~Hz}, 1 \mathrm{H}), 6.16(\mathrm{~d}, J=1.91 \mathrm{~Hz}, 1 \mathrm{H}), 3.89(\mathrm{~s}, 3 \mathrm{H}))$. 
2.2.8. Synthesis of 2-(3,4-Dihydroxyphenyl)-5-hydroxy-7-methoxy-4H-chromen-4-one (V8)

(V8): ${ }^{1} \mathrm{H}$ NMR (400 Mhz, DMSO-d 6 ) $\delta(12.99$ (br, s, 1H), (7.47-7.44) $(\mathrm{m}, 2 \mathrm{H}), 6.90(\mathrm{~d}$, $J=8.21 \mathrm{~Hz}, 1 \mathrm{H}),(6.74-6.73)(\mathrm{m}, 2 \mathrm{H}), 6.38(\mathrm{~d}, J=2.24 \mathrm{~Hz}, 1 \mathrm{H}), 3.88(\mathrm{~s}, 3 \mathrm{H}))$.

2.2.9. Synthesis of 2-(3,4-Dimethoxyphenyl)-5-hydroxy-7-methoxy-4H-chromen-4-one (V9)

(V9): ${ }^{1} \mathrm{H}$ NMR (400 Mhz, $\left.\mathrm{CDCl}_{3}\right) \delta\left(12.80(\mathrm{~s}, 1 \mathrm{H}), 7.53\left(\mathrm{dd}, J_{1}=8.48 \mathrm{~Hz}, J_{2}=2.12 \mathrm{~Hz}\right.\right.$, $1 \mathrm{H}), 7.34(\mathrm{~d}, J=2.08 \mathrm{~Hz}, 1 \mathrm{H}), 6.98(\mathrm{~d}, J=8.54 \mathrm{~Hz}, 1 \mathrm{H}), 6.50(\mathrm{~d}, J=2.24 \mathrm{~Hz}, 1 \mathrm{H}), 6.37(\mathrm{~d}$, $J=2.22 \mathrm{~Hz}, 1 \mathrm{H}), 3.98(\mathrm{~s}, 3 \mathrm{H}), 3.97(\mathrm{~s}, 3 \mathrm{H}), 3.89(\mathrm{~s}, 3 \mathrm{H}))$.

2.2.10. Synthesis of 2-(3,4-Dimethoxyphenyl)-5,7-dimethoxy-4H-chromen-4-one (V10)

(V10): ${ }^{1} \mathrm{H}$ NMR $(400 \mathrm{Mhz}$, DMSO-d 6$) \delta\left(7.64\left(\mathrm{dd}, J_{1}=8.48 \mathrm{~Hz}, J_{2}=2.16 \mathrm{~Hz}, 1 \mathrm{H}\right), 7.53\right.$ $(\mathrm{d}, J=2.12,1 \mathrm{H}), 7.11(\mathrm{~d}, J=8.62,1 \mathrm{H}), 6.87(\mathrm{~d}, J=2.30,1 \mathrm{H}), 6.77(\mathrm{~s}, 1 \mathrm{H}), 6.50(\mathrm{~d}, J=2.30$, $1 \mathrm{H}), 3.91(\mathrm{~s}, 3 \mathrm{H}), 3.88(\mathrm{~s}, 3 \mathrm{H}), 3.85(\mathrm{~s}, 3 \mathrm{H}), 3.83(\mathrm{~s}, 3 \mathrm{H}))$.

\subsubsection{2-Phenylchromen-4-one (V12)}

(V12): ${ }^{1} \mathrm{H}$ NMR $\left(400 \mathrm{Mhz}, \mathrm{CDCl}_{3}\right) \delta\left(8.24\left(\mathrm{dd}, 1 \mathrm{H}, J_{1}=1.66 \mathrm{~Hz}, J_{2}=7.94 \mathrm{~Hz}\right),(7.96-7.93)\right.$ $(\mathrm{m}, 2 \mathrm{H}),(7.73-7.69)(\mathrm{m}, 1 \mathrm{H}),(7.59-7.57)(\mathrm{m}, 1 \mathrm{H}),(7.56-7.53)(\mathrm{m}, 3 \mathrm{H}), 7.45-7.41(\mathrm{~m}, 1 \mathrm{H}), 6.84$ $(\mathrm{s}, 1 \mathrm{H}))$.

\subsection{Effect of Velutin Derivatives on ABTS Radical Scavenging Activity}

The ABTS radical scavenging activity of the twelve velutin derivatives or arbutin (positive control) was then evaluated in the concentration range 50-200 $\mu \mathrm{M}$, and Table 2 lists their half-maximal effective concentration $\left(\mathrm{EC}_{50}\right)$ values. Most derivatives, except V10, showed dose-dependent radical scavenging activity (data not shown), with $\mathrm{EC}_{50}$ values ranging (5.47-100.13) $\mu \mathrm{M}$ (Table 2). In particular, V8 and V11 (luteolin) compounds with a 1,2-diol-type structure, showed a better radical scavenging activity than the other derivatives. In contrast, the V10 or V12 compounds substituted with methoxy or hydrogen group at $\mathrm{C} 5, \mathrm{C} 7, \mathrm{C}^{\prime}$, and $\mathrm{C}^{\prime}$ ' of the backbone, had no significant effect on radical scavenging activity. These results indicated that the presence of hydroxyl group on the velutin backbone was critical for its radical scavenging activity. Furthermore, increase in the number of methoxy functionality at $\mathrm{C} 5, \mathrm{C} 7, \mathrm{C}^{\prime}$, and $\mathrm{C}^{\prime}$ of the backbone lowered ABTS radical scavenging activity.

Table 2. Inhibitory effect of velutin derivatives on ABTS radical scavenging and mushroom tyrosinase activities.

\begin{tabular}{ccc}
\hline Compound & $\begin{array}{c}\text { EC }_{\mathbf{5 0}} \text { in ABTS Radical } \\
\text { Scavenging Activity }(\mu \mathbf{M})\end{array}$ & $\begin{array}{c}\text { IC }_{\mathbf{5 0}} \text { in Mushroom } \\
\text { Tyrosinase Activity }(\mu \mathbf{M})\end{array}$ \\
\hline V1 & 23.13 & 910.1 \\
V2 & 21.85 & N.D. \\
V3 & 23.33 & N.D. \\
V4 & 55.73 & 203.5 \\
V5 & 96.57 & N.D. \\
V6 & 23.73 & N.D. \\
V7 & 22.07 & N.D. \\
V8 & 5.47 & 202.3 \\
V9 & 100.13 & 715.2 \\
V10 & N.D. & N.D. \\
V11 & 6.13 & 36.7 \\
V12 & N.D. & N.D. \\
Arbutin & 12.67 & 376.0 \\
\hline
\end{tabular}




\subsection{Effect of Velutin Derivatives on Mushroom Tyrosinase Inhibitory Activity}

To further understand the effect of the electrostatic potential of the derivatives on their inhibitory activities against tyrosinase, the inhibitory effect of the twelve velutin derivatives on mushroom tyrosinase was evaluated. The five velutin derivatives V1, V4, V8, V9, and V11 had potential inhibitory activity against mushroom tyrosinase, with $\mathrm{IC}_{50}$ values ranging 37-910 $\mu \mathrm{M}$, but the other seven velutin derivatives V2, V3, V5, V6, V9, V10, and V12 had no significant effect (Table 2). These results indicated that the number of hydroxyl groups at $\mathrm{C} 5, \mathrm{C} 7, \mathrm{C}^{\prime}$, and $\mathrm{C}^{\prime}$ of the flavone backbone was an important factor for their inhibitory activity against tyrosinase. In particular, the V11 compound showed the lowest $\mathrm{IC}_{50}$ value in the twelve derivatives, while V10 and V12 had no significant effect on tyrosinase activity, suggesting that the existence of hydroxyl group, rather than methoxy or hydrogen group, at $\mathrm{C} 5, \mathrm{C} 7, \mathrm{C}^{\prime}$, and $\mathrm{C}^{\prime}$ of the flavone backbone was more important for its anti-tyrosinase effect. Furthermore, hydroxyl and methoxy functionalities at the $\mathrm{R}^{1}$ and $\mathrm{R}^{2}$ positions might play an important role in the inhibition of tyrosinase.

\subsection{Cytotoxicity of Velutin Derivatives in Melanoma Cells}

Cytotoxicity is a concern for any potential compound, and thus after treating the cells with derivatives, we quantitatively measured the cytotoxicity of the eleven velutin derivatives that had the potential to inhibit melanogenesis, except for V12, which had no potential to inhibit melanogenesis through MTT assay. Nine derivatives, excluding V8, V10, and V11, had no significant effect on cell viability at concentrations up to $20 \mu \mathrm{M}$ (data not shown). However, the treatment with V8, V10, and V11, induced cell death in a concentration-dependent manner, with death rates of $71.8,24.0$, and $69.7 \%$, respectively, at $20 \mu \mathrm{M}$ (Figure 2). This result indicates that the 1,2-diol form with hydroxyl groups at the $\mathrm{C}^{\prime}$ and $\mathrm{C}^{\prime}$ positions of the flavone induced apoptosis in melanoma cells, which was consistent with the previous report explaining the cytotoxicity of flavonoid derivatives in 1,2-diol form, such as catechin and epicatechin [19].

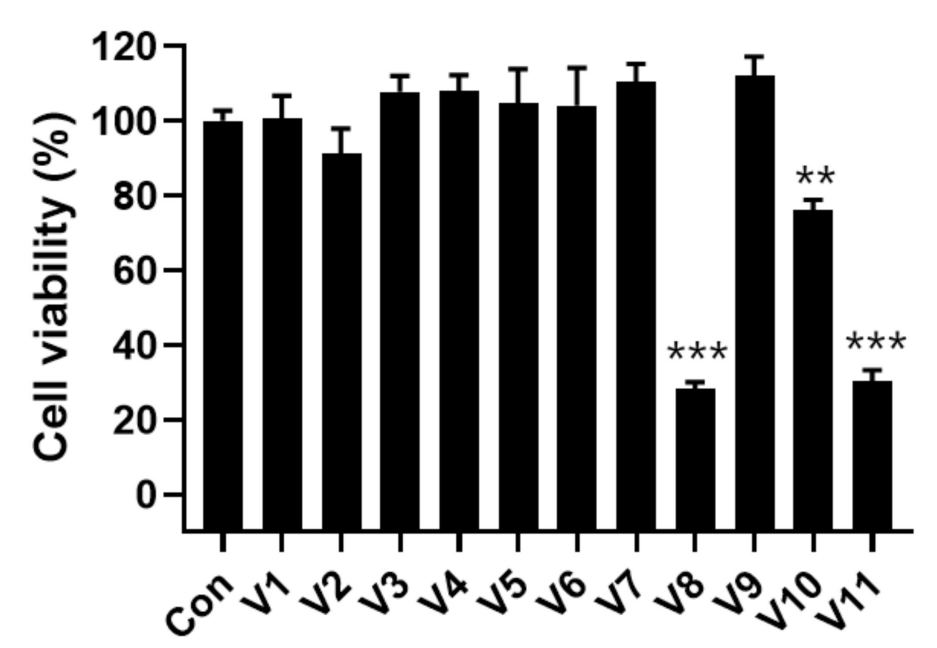

Figure 2. Cytotoxicity of velutin derivatives in the B16F10 melanoma cells. B16F10 cells were treated with $0.1 \%$ DMSO as vehicle, or with $20 \mu \mathrm{M}$ of each derivative, for $24 \mathrm{~h}$. Cell viability was determined by the MTT assay, as described in the Experimental Section. Data are expressed as the mean \pm SD of three independent experiments ${ }^{* *} p<0.005,{ }^{* * *} p<0.001$ compared to the control cells).

\subsection{Effect of Velutin Derivatives on Melanogenesis in Melanoma Cells}

Next, the effects of the nine velutin derivatives excluding V8 and V11, which have cytotoxicity, on melanogenesis stimulated by $\alpha$-melanocyte stimulating hormone ( $\alpha-\mathrm{MSH})$ in melanoma cells were determined. Treatment with $\alpha-\mathrm{MSH}$ stimulated a 1.9-fold increase of the melanin content of the melanoma cells (Figure 3A). We found that $\alpha-\mathrm{MSH}$-stimulated melanogenesis was completely inhibited by V1 and V2 $(p<0.001)$, and partially inhib- 
ited by V3 (50.7\%, $p<0.005)$, V4 (69.1\%, $p<0.001)$, and V5 (39.3\%, $p<0.005)$, while $\alpha-\mathrm{MSH}$-stimulated melanogenesis was not significantly changed by V7, V9, and V10 (Figure 3A). Surprisingly, the V6 derivative significantly increased melanin synthesis by 3.0-fold $(p<0.001)$. These results suggest that the velutin derivatives with similar structures but different substitution groups, have different biological activity on melanogenesis. Further, the inhibitory activities of the nine velutin derivatives on $\alpha-\mathrm{MSH}$-mediated intracellular tyrosinase activation were determined, since this enzyme plays a key role in melanogenesis. Treatment with $\alpha-\mathrm{MSH}$ induced an approximately 1.7 -fold activation of tyrosinase in B16F10 cells (Figure 3B). Four derivatives V1 (87\%, $p<0.001)$, V3 $(97 \%, p<0.001)$, V4 (100\%, $p<0.001)$, and V5 (80\%, $p<0.001)$ reversed tyrosinase activation mediated by $\alpha-\mathrm{MSH}$, whereas four other derivatives V2, V7, V9, and V10 did not (Figure 3B). These results indicate that the four derivatives V1, V3, V4, and V5 inhibited $\alpha-\mathrm{MSH}$-induced melanin synthesis, by inhibiting the intracellular tyrosinase activity in B16F10 cells.

A

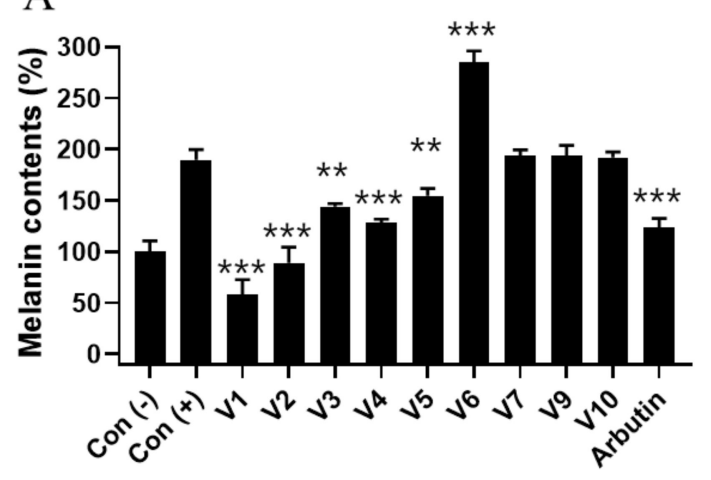

B

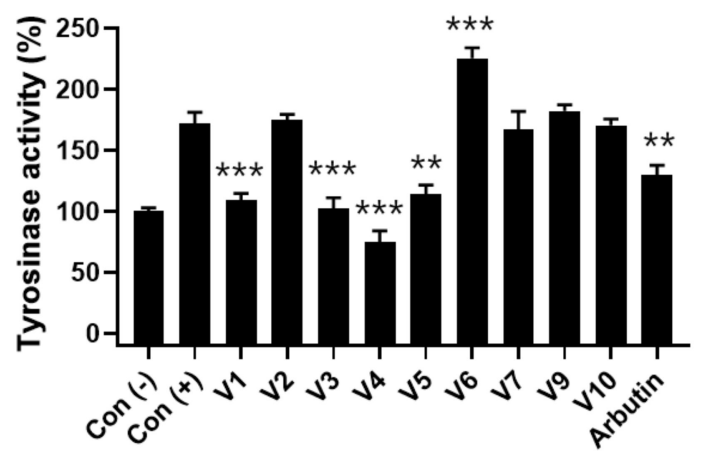

Figure 3. Effect of velutin derivatives on intracellular melanin synthesis in B16F10 melanoma cells. B16F10 cells were treated with $0.1 \%$ DMSO as vehicle, or with $10 \mu \mathrm{M}$ of each derivative, for $48 \mathrm{~h}$. (A) Melanin content in the B16F10 cells was determined using a photometric method, as described in the Experimental Section. (B) Cellular tyrosinase activity was determined by measuring dopachrome generated by the enzymatic reaction of cell lysates with L-DOPA. Data are expressed as the mean $\pm \mathrm{SD}$ of three independent experiments $\left({ }^{* *} p<0.005,{ }^{* * *} p<0.001\right.$ as compared to $\alpha$-MSH-stimulated B16F10 cells).

\subsection{In Silico Molecular Docking Simulation of Enzyme Inhibition}

To predict the interaction between velutin derivatives and tyrosinase, an in silico molecular docking study was performed using the Maestro software. The molecular docking study revealed that V9 and V10 derivatives, highly substituted with methoxy groups, did not bind to the enzyme (Table 3); this result was consistent with our results obtained from the in vitro experiment. Further, most of the flavone derivatives, except V9 and V10, interact with tyrosinase with binding energies ranging from -4.983 to $-5.677 \mathrm{kcal} / \mathrm{mol}$ (Table 3). The two derivatives, V1 and V4, showed inhibitory activity against tyrosinase activity in melanoma cells, with docking scores of -5.043 and $-5.136 \mathrm{kcal} / \mathrm{mol}$, respectively. They were stabilized by $\pi-\pi$ stacking with Phe 264 (A and C ring) and His 259 (B ring), and $\pi$-cation interaction with Arg 268 (A ring), as shown in Figure 4. Two derivatives that were highly substituted with hydroxyl groups, V7 and V11, formed hydrogen bonds with enzyme, and showed relatively high docking scores of -5.174 and $-5.677 \mathrm{kcal} / \mathrm{mol}$, respectively. This result was consistent with our results, showing relatively low $\mathrm{IC}_{50}$ values against tyrosinase activity obtained from in vitro experiment. However, V7 had no effect on melanogenesis and tyrosinase activity in melanoma cells, while V11 showed cytotoxicity in melanoma cells. 
Table 3. Binding sites and docking scores of velutin derivatives in tyrosinase.

\begin{tabular}{|c|c|c|c|c|}
\hline \multirow{2}{*}{ Ligand } & \multirow{2}{*}{$\begin{array}{l}\text { Docking Score } \\
\text { (Kcal/mol) }\end{array}$} & \multicolumn{3}{|c|}{ Key Interaction } \\
\hline & & H Bond & $\pi-\pi$ Stacking & $\pi$-Cation \\
\hline V1 & -5.043 & & $\begin{array}{c}\text { Phe } 264 \text { (A, C ring) } \\
\text { His } 259 \text { (B ring) }\end{array}$ & Arg 268 (A ring) \\
\hline V2 & -5.093 & & $\begin{array}{c}\text { Phe } 264 \text { (A, C ring) } \\
\text { His } 259 \text { (B ring) }\end{array}$ & Arg 268 (A ring) \\
\hline V3 & -5.223 & & $\begin{array}{l}\text { Phe } 264 \text { (B ring) } \\
\text { His } 263 \text { (A ring) }\end{array}$ & Arg 268 (A ring) \\
\hline V4 & -5.136 & & $\begin{array}{c}\text { Phe } 264 \text { (A, C ring) } \\
\text { His } 259, \text { His } 85 \text { (B ring) }\end{array}$ & Arg 268 (A ring) \\
\hline V5 & -5.321 & & & Arg 268 (A, C ring) \\
\hline V6 & -4.983 & & $\begin{array}{l}\text { Phe } 264 \text { (A, C ring) } \\
\text { His } 259 \text { (B ring) }\end{array}$ & Arg 268 (A ring) \\
\hline V7 & -5.174 & Glu $322\left(C^{\prime}-4\right)$ & $\begin{array}{l}\text { His } 85 \text { (A ring) } \\
\text { His } 244 \text { ( } \mathrm{B}, \mathrm{C} \text { ring) }\end{array}$ & \\
\hline V8 & -5.004 & & $\begin{array}{l}\text { Phe } 264 \text { (C ring) } \\
\text { His } 263 \text { (B ring) }\end{array}$ & Arg 268 (A ring) \\
\hline V9 & No pose & & & \\
\hline V10 & No pose & & & \\
\hline V11 & -5.677 & Met 280 (C-7) & $\begin{array}{l}\text { His } 263 \text { (A ring) } \\
\text { Phe } 264 \text { (B ring) }\end{array}$ & \\
\hline
\end{tabular}

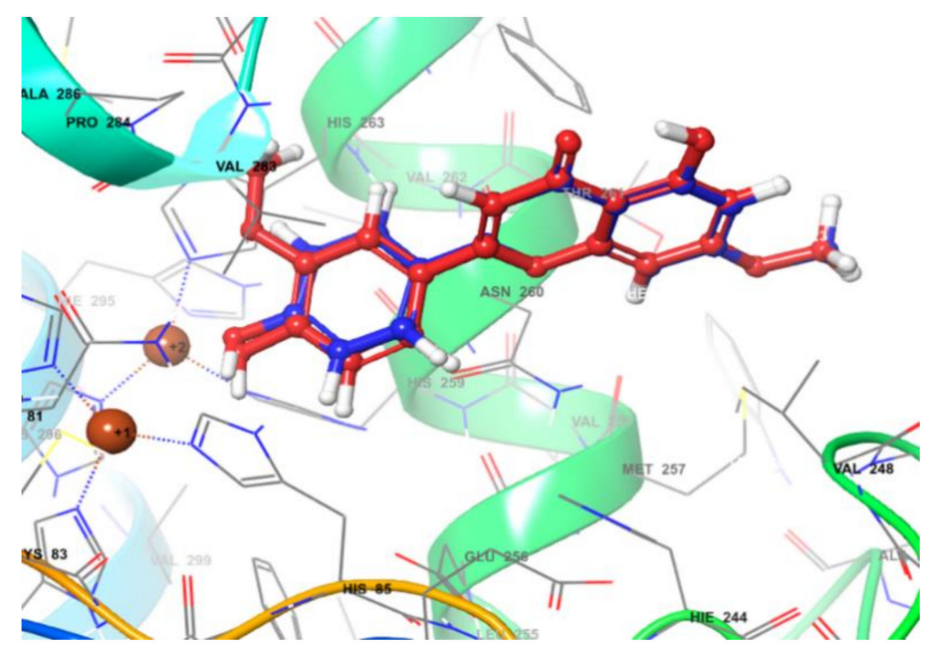

Figure 4. Molecular docking of tyrosinase binding with the V1 and V4 derivatives (V1: red sticks and V4: blue sticks).

\section{Experimental Section}

\subsection{Chemistry}

Commercially available reagents were used without additional purification. All reaction mixtures were magnetically stirred, and were monitored by thin-layer chromatography, using silica gel pre-coated glass plates visualized with UV light, and then developed using either iodine or a solution of anisaldehyde. Flash column chromatography was carried out using silica gel ((230-400) mesh). ${ }^{1} \mathrm{H}$ NMR (400 Mhz) and spectra were recorded by NMR spectrometry. Deuterated chloroform was used as the solvent and chemical shift values $(\delta)$ were reported in parts per million, relative to the residual signals of this solvent $[\delta 7.26$ for ${ }^{1} \mathrm{H}$ (chloroform- $d$ ), $\delta 2.50$ for ${ }^{1} \mathrm{H}$ (dimethyl sulfoxide- $d$ )].

\subsection{Materials}

Reagents such as 2,2'-azinobis(3-ethylbenzothiazoline-6-sulfonic acid (ABTS) and 3-(4,5-dimethylthiazol-2-yl)-2,5-diphenyltetrazolium bromide (MTT), $\alpha$-melanocyte stimu- 
lating hormone ( $a-\mathrm{MSH})$, and enzymes, such as mushroom tyrosinase, were obtained from Sigma-Aldrich (St. Louis, MO, USA). Potassium persulfate $\left(\mathrm{K}_{2} \mathrm{~S}_{2} \mathrm{O}_{8}\right)$, pyrocatechol violet, and 3,4-dihydroxy-L-phenylalanine (L-DOPA) were purchased from Alfa Aesar (Haverhill, MA, USA).

\subsection{Determination of ABTS Free Radical Scavenging Activity}

In order to evaluate the antioxidant activity of the velutin derivatives, the ABTS radical scavenging activity was determined, as previously described [20]. To generate the ABTS radical, $10 \mathrm{~mL}$ of $7 \mathrm{mM}$ ABTS was mixed with $176 \mu \mathrm{L}$ of $140 \mathrm{mM}$ potassium peroxydisulfate in $\mathrm{dH}_{2} \mathrm{O}$, and incubated in the dark at room temperature (RT) for $16 \mathrm{~h}$, prior to use. The ABTS radical solution was diluted with absolute methanol, to obtain an absorbance of near 0.7 at $734 \mathrm{~nm}$. Aliquots of $100 \mu \mathrm{L}$ of each derivative in the indicated concentration range 2 to $200 \mu \mathrm{M}$ were added to $100 \mu \mathrm{L}$ of the diluted ABTS radical solution, and incubated for $10 \mathrm{~min}$ in the dark at RT. The absorbance was then measured at $732 \mathrm{~nm}$ using a SpectraMax M5 Multi-Mode microplate reader (Molecular Devices, Sunnyvale, CA, USA). The ABTS radical scavenging activity was calculated as follows:

$$
\text { ABTS radical scavenging activity }(\%)=1-(\text { Asample } / \text { Acontrol }) \times 100
$$

\subsection{In Vitro Mushroom Tyrosinase Inhibition}

The inhibitory effect of velutin derivatives on tyrosinase activity was assessed by the amount of dopachrome synthesized from the catalytic reaction of tyrosinase $[8,21]$. In brief, $50 \mu \mathrm{L}$ of velutin derivatives in the concentration range of $0.01-1 \mathrm{mM}$ was mixed with $50 \mu \mathrm{L}$ of $50 \mathrm{U} / \mathrm{mL}$ mushroom tyrosinase, in $50 \mathrm{mM}$ phosphate buffered saline (PBS; $8.1 \mathrm{mM}$ $\mathrm{Na}_{2} \mathrm{HPO}_{4}, 1.2 \mathrm{mM} \mathrm{KH}_{2} \mathrm{PO}_{4}, \mathrm{pH} 6.8,2.7 \mathrm{mM} \mathrm{KCl}, 138 \mathrm{mM} \mathrm{NaCl}$ ) in a 96-well plate, and incubated for $30 \mathrm{~min}$ at RT. Then, $100 \mu \mathrm{L}$ of $0.4 \mathrm{mM}$ L-tyrosine was added to each well, followed by incubation for an additional $10 \mathrm{~min}$ at $37^{\circ} \mathrm{C}$. The absorbance of the resulting solution was measured at $475 \mathrm{~nm}$, using a SpectraMax M5 Multi-Mode microplate reader.

\subsection{Cell Culture}

B16F10 murine melanoma cells were cultured in DMEM medium (Gibco, Gaithersburg, USA) supplemented with $10 \%$ heat-inactivated fetal bovine serum (Gibco), 100 units $/ \mathrm{mL}$ penicillin, and $100 \mu \mathrm{g} / \mathrm{mL}$ streptomycin (Gibco), at $37^{\circ} \mathrm{C}$ under humidified $5 \% \mathrm{CO}_{2}$.

\subsection{Cell Viability}

The viability of B16F10 cells was determined using an MTT assay, as previously described [22]. In brief, B16F10 cells were seeded in 24-well plates at a density of $1 \times 10^{4}$ cells per well. After $24 \mathrm{~h}$, the cells were treated with the indicated concentrations of velutin derivatives for $48 \mathrm{~h}$. The cells were then incubated with MTT solution for $4 \mathrm{~h}$, and the reduced formazan crystals were dissolved in DMSO. The resulting solution was transferred to 96-well plates, and the absorbance was measured at $540 \mathrm{~nm}$, using a SpectraMax M5 Multi-Mode microplate reader.

\subsection{Melanin Content Determination}

The melanin content was determined as previously described, with some modifications [23]. The melanoma cells were cultured in a 6-well plate for $24 \mathrm{~h}$. They were treated with the indicated concentrations of velutin derivatives for a further $48 \mathrm{~h}$, in the presence of $100 \mathrm{nM} \alpha-\mathrm{MSH}$. After washing twice with chilled Dulbecco's phosphate buffered saline supplemented with calcium chloride and magnesium chloride (D-PBS, Gibco), the resulting cells were detached by incubation with trypsin-EDTA solution. After centrifugation at $1000 \mathrm{rpm}$ for $3 \mathrm{~min}$, the cell pellet was dissolved in $150 \mu \mathrm{L}$ of $1 \mathrm{M} \mathrm{NaOH}$ containing $10 \%$ DMSO for $1 \mathrm{~h}$ at $60^{\circ} \mathrm{C}$. The melanin content was determined by the absorbance at $405 \mathrm{~nm}$, using the microplate reader. 


\subsection{Determination of Cellular Tryosinase Activity in Melanoma Cells}

Tyrosinase activity in B16 cells was examined on the basis of the amount of dopachrome produced from the catalytic reaction of intracellular tyrosinase [24]. In brief, the melanoma cells were cultured in a 6-well plate for $24 \mathrm{~h}$, followed by treatment with different concentrations of velutin derivatives for a further $48 \mathrm{~h}$, in the presence of $100 \mathrm{nM}$ of $\alpha-$ MSH. After washing twice with ice-cold D-PBS, the cells were lysed in $200 \mu \mathrm{L}$ of radioimmunoprecipitation assay (RIPA) buffer (Sigma-Aldrich), containing protease and phosphatase inhibitors. After centrifugation of the cell lysate collected from each well at $15,000 \times g$ for $15 \mathrm{~min}, 100 \mu \mathrm{L}$ of supernatant was mixed with $100 \mu \mathrm{L}$ of $1 \mathrm{mM}$ L-DOPA in PBS (pH 6.8), followed by incubation for $30 \mathrm{~min}$ at $37^{\circ} \mathrm{C}$. The absorbance of dopachrome was measured at $475 \mathrm{~nm}$ using the microplate reader. Data were normalized with protein concentration, determined by bicinchoninic acid assay.

\subsection{Molecular Modeling}

The crystal structure of mushroom tyrosinase for molecular modeling was an Agaricus bisporus tyrosinase (PDB dose: 2Y9X) obtained from the Protein Data Bank (PDB). The enzyme was prepared by using the protein wizard preparation workflow embedded in the Maestro program (Maestro, version 11.9.011, Schrödinger, LLC, New York, NY, USA, 2019). Water, and all the other molecules present in the pdb files, were removed. Molecular docking was performed using the Induced Fit Docking (IFD) protocol (Schrödinger Suite 2019 Induced Fit Docking protocol), as previously reported [25].

\subsection{Statistical Analysis}

All data in this study were expressed as the mean \pm standard deviation (SD) from three independent experiments. Statistical analyses were performed using the Graph-Pad Prism 8.0 (GraphPad Software Inc., La Jolla, CA, USA). The differences between the mean values of the control and the exposed groups were analyzed using one-way analysis of variance (ANOVA). A value of $p<0.05$ was considered to be statistically significant.

\section{Conclusions}

In this study, we obtained twelve velutin derivatives through chemical synthesis, and comparatively analyzed the relationship between the chemical structure of these derivatives and their activity related to melanin synthesis. The SAR study revealed that the substitution of functional groups at $\mathrm{C} 5, \mathrm{C} 7, \mathrm{C}^{\prime}{ }^{\prime}$, and $\mathrm{C} 4^{\prime}$ of the flavone backbone affected the biological activities related to melanin synthesis (Figure 5). The coexistence of hydroxyl and methoxy at $\mathrm{R}^{1}$ and $\mathrm{R}^{2}$, respectively, was essential for inhibiting tyrosinase activity. However, the 1,2-diol compounds substituted at $R^{3}$ and $R^{4}$ induced apoptosis of melanoma cells. Further, substitution at $R^{3}$ and $R^{4}$ with methoxy or hydrogen was essential for inhibiting melanogenesis. This study would be helpful for the development of natural-derived functional materials, to regulate melanin synthesis.

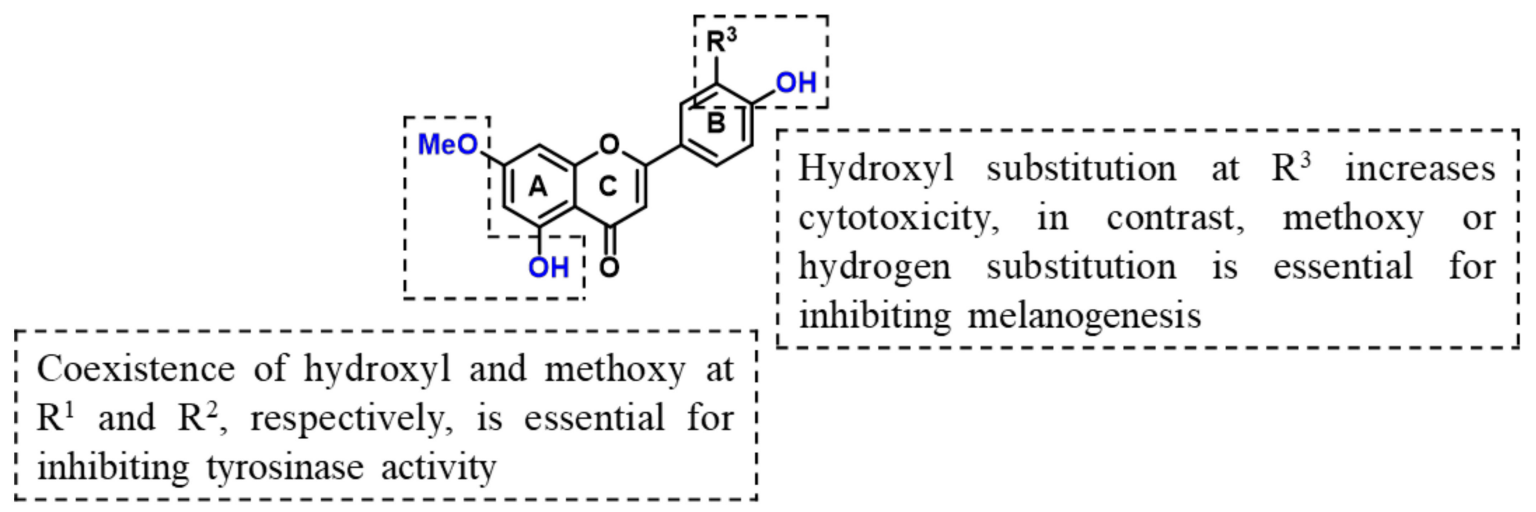

Figure 5. Velutin derivatives along with their structure-activity relationship for the inhibition of melanogenesis. 
Author Contributions: Conceptualization, S.-H.J. and K.L.; methodology, S.-H.J.; software, J.K.; validation, S.-H.J. and K.L.; formal analysis, S.-H.J. and K.L.; investigation, H.-Y.H. and J.-W.C.; resources, K.L.; data curation, S.-H.J. and H.-Y.H.; writing—original draft preparation, S.-H.J. and H.Y.H.; writing-review and editing, K.L.; visualization, S.-H.J. and H.-Y.H.; supervision, K.L.; project administration, K.L.; funding acquisition, K.L. All authors have read and agreed to the published version of the manuscript.

Funding: This work was supported by a 2017 Research Grant from Kangwon National University (No. 520170418).

Institutional Review Board Statement: Not applicable.

Informed Consent Statement: Not applicable.

Data Availability Statement: The data presented in this study are available on request from the corresponding author.

Conflicts of Interest: The authors declare that they have no conflict of interest.

Sample Availability: Samples of the all compounds are available from the authors.

\section{References}

1. Martens, S.; Mithofer, A. Flavones and flavone synthases. Phytochemistry 2005, 66, 2399-2407. [CrossRef]

2. Harborne, J.B.; Williams, C.A. Advances in flavonoid research since 1992. Phytochemistry 2000, 55, 481-504. [CrossRef]

3. Cazarolli, L.H.; Zanatta, L.; Alberton, E.H.; Figueiredo, M.S.; Folador, P.; Damazio, R.G.; Pizzolatti, M.G.; Silva, F.R. Flavonoids: Prospective drug candidates. Mini Rev. Med. Chem. 2008, 8, 1429-1440. [CrossRef] [PubMed]

4. Cushnie, T.P.; Lamb, A.J. Recent advances in understanding the antibacterial properties of flavonoids. Int. J. Antimicrob. Agents 2011, 38, 99-107. [CrossRef] [PubMed]

5. Hyun, J.; Woo, Y.; Hwang, D.S.; Jo, G.; Eom, S.; Lee, Y.; Park, J.C.; Lim, Y. Relationships between structures of hydroxyflavones and their antioxidative effects. Bioorg. Med. Chem. Lett. 2010, 20, 5510-5513. [CrossRef]

6. Fu, T.; Chai, B.; Shi, Y.; Dang, Y.; Ye, X. Fargesin inhibits melanin synthesis in murine malignant and immortalized melanocytes by regulating PKA/CREB and P38/MAPK signaling pathways. J. Dermatol. Sci. 2019, 94, 213-219. [CrossRef]

7. Wang, L.; Gan, Z.F.; Guo, D.; Xia, H.L.; Patrice, F.T.; Hafez, M.E.; Li, D.W. Electrochemistry-Regulated Recyclable SERS Sensor for Sensitive and Selective Detection of Tyrosinase Activity. Anal. Chem. 2019, 91, 6507-6513. [CrossRef] [PubMed]

8. Jung, S.H.; Kim, J.; Eum, J.; Choe, J.W.; Kim, H.H.; Kee, Y.; Lee, K. Velutin, an Aglycone Extracted from Korean Mistletoe, with Improved Inhibitory Activity against Melanin Biosynthesis. Molecules 2019, 24, 2549. [CrossRef]

9. Alam, M.B.; Bajpai, V.K.; Lee, J.; Zhao, P.; Byeon, J.H.; Ra, J.S.; Majumder, R.; Lee, J.S.; Yoon, J.I.; Rather, I.A.; et al. Inhibition of melanogenesis by jineol from Scolopendra subspinipes mutilans via MAP-Kinase mediated MITF downregulation and the proteasomal degradation of tyrosinase. Sci. Rep. 2017, 7, 45858. [CrossRef]

10. Rose, P.T. Pigmentary disorders. Med. Clin. North Am. 2009, 93, 1225-1239. [CrossRef]

11. Lee, S.Y.; Baek, N.; Nam, T.G. Natural, semisynthetic and synthetic tyrosinase inhibitors. J. Enzyme Inhib. Med. Chem. 2016, 31, 1-13. [CrossRef]

12. Okombi, S.; Rival, D.; Bonnet, S.; Mariotte, A.M.; Perrier, E.; Boumendjel, A. Discovery of benzylidenebenzofuran-3(2H)-one (aurones) as inhibitors of tyrosinase derived from human melanocytes. J. Med. Chem. 2006, 49, 329-333. [CrossRef] [PubMed]

13. Lim, J.; Nam, S.; Jeong, J.H.; Kim, M.J.; Yang, Y.; Lee, M.S.; Lee, H.G.; Ryu, J.H.; Lim, J.S. Kazinol U inhibits melanogenesis through the inhibition of tyrosinase-related proteins via AMP kinase activation. Br. J. Pharmacol. 2019, 176, 737-750. [CrossRef]

14. Momtaz, S.; Lall, N.; Basson, A. Inhibitory activities of mushroom tyrosine and DOPA oxidation by plant extracts. South Afr. J. Bot. 2008, 74, 577-582. [CrossRef]

15. Xie, C.H.; Kang, J.; Li, Z.M.; Schauss, A.G.; Badger, T.M.; Nagarajan, S.; Wu, T.; Wu, X.L. The acai flavonoid velutin is a potent anti-inflammatory agent: Blockade of LPS-mediated TNF-alpha and IL-6 production through inhibiting NF-kappa B activation and MAPK pathway. J. Nutr. Biochem. 2012, 23, 1184-1191. [CrossRef]

16. Kang, J.; Xie, C.; Li, Z.; Nagarajan, S.; Schauss, A.G.; Wu, T.; Wu, X. Flavonoids from acai (Euterpe oleracea Mart.) pulp and their antioxidant and anti-inflammatory activities. Food Chem. 2011, 128, 152-157. [CrossRef]

17. Yamasaki, K.; Hishiki, R.; Kato, E.; Kawabata, J. Study of Kaempferol Glycoside as an Insulin Mimic Reveals Glycon To Be the Key Active Structure. ACS Med. Chem. Lett. 2011, 2, 17-21. [CrossRef]

18. Cabrera, M.; Simoens, M.; Falchi, G.; Lavaggi, M.L.; Piro, O.E.; Castellano, E.E.; Vidal, A.; Azqueta, A.; Monge, A.; De Cerain, A.L.; et al. Synthetic chalcones, flavanones, and flavones as antitumoral agents: Biological evaluation and structure-activity relationships. Bioorg. Med. Chem. 2007, 15, 3356-3367. [CrossRef] [PubMed]

19. Grace, M.H.; Wilsonb, G.R.; Kandil, F.E.; Dimitriadis, E.; Coates, R.M. Characteristic flavonoids from Acacia burkittii and A. acuminata heartwoods and their differential cytotoxicity to normal and leukemia cells. Nat. Prod. Commun. 2009, 4, 69-76.

20. Re, R.; Pellegrini, N.; Proteggente, A.; Pannala, A.; Yang, M.; Rice-Evans, C. Antioxidant activity applying an improved ABTS radical cation decolorization assay. Free Radic. Biol. Med. 1999, 26, 1231-1237. [CrossRef] 
21. Chang, T.S.; Ding, H.Y.; Tai, S.S.K.; Wu, C.Y. Mushroom tyrosinase inhibitory effects of isoflavones isolated from soygerm koji fermented with Aspergillus oryzae BCRC 32288. Food Chem. 2007, 105, 1430-1438. [CrossRef]

22. Purushotham, G.; Padma, Y.; Nabiha, Y.; Venkata Raju, R.R. In vitro evaluation of anti-proliferative, anti-inflammatory and pro-apoptotic activities of the methanolic extracts of Andrographis nallamalayana Ellis on A375 and B16F10 melanoma cell lines. 3 Biotech 2016, 6, 212. [CrossRef] [PubMed]

23. Huang, H.C.; Hsieh, W.Y.; Niu, Y.L.; Chang, T.M. Inhibitory effects of adlay extract on melanin production and cellular oxygen stress in B16F10 melanoma cells. Int. J. Mol. Sci. 2014, 15, 16665-16679. [CrossRef] [PubMed]

24. Baron, R.; Zayats, M.; Willner, I. Dopamine-, L-DOPA-, adrenaline-, and noradrenaline-induced growth of Au nanoparticles: Assays for the detection of neurotransmitters and of tyrosinase activity. Anal. Chem. 2005, 77, 1566-1571. [CrossRef] [PubMed]

25. Uysal, S.; Ugurlu, A.; Zengin, G.; Baloglu, M.C.; Altunoglu, Y.C.; Mollica, A.; Custodio, L.; Neng, N.R.; Nogueira, J.M.F.; Mahomoodally, M.F. Novel in vitro and in silico insights of the multi-biological activities and chemical composition of Bidens tripartita L. Food Chem. Toxicol. 2018, 111, 525-536. [CrossRef] [PubMed] 